\title{
PIERRE, G. God Never Meant for Us to Die: The Emergence of Evil in the Light of the Genesis Creation Account Eugene, OR: Wipf \& Stock, 2020, 204 p. ISBN: 978-1532699627
}

Professor associado de Sagrada Escritura e Teologia na Universidade Menonita do Canadá e no Seminário Mennonite Brethren, em Winnipeg, Pierre Gilbert é doutor em Antigo Testamento pela Universidade de Montréal. É autor de vários artigos religiosos e do livro Demons, Lies, \& Shadows. A Plea for a Return to Text and Reason.

Nesta obra, o autor lida com o problema do mal e a afirmação de certos segmentos religiosos dentro do cristianismo de que o sofrimento e a morte são consequências de uma queda primordial, conforme relatado no livro de Gênesis. Embora muitos teólogos contemporâneos já abandonaram essa interpretação, Gilbert sente que ainda há argumentos em favor dessa posição tradicional.

No capítulo $1, \mathrm{o}$ autor discute as diferentes abordagens que são utilizadas para lidar com a questão do mal. Há aqueles que optam por uma releitura da teologia sobre Deus, enquanto outros se contentam em desqualificar a repugnância do mal, seja incorporando-o à tecedura da existência ou tratando-o como uma ilusão humana. Há aqueles que interpretam o mal dentro do contexto de uma guerra cósmica, como o faz Gregory Boyd, enquanto outros se contentam em descartar toda a discussão por falta de evidências conclusivas. Gilbert argumenta que a melhor defesa não é partindo do problema, mas se iniciando pelo estudo de Deus. Ele ressalta que nas religiões da antiga Mesopotâmia, as divindades eram tanto boas quanto más. Uma vez que a natureza era considerada um barômetro da vontade dos deuses, as antigas civilizações não viam problema no fato da natureza conter males. Contra essas interpretações, os primeiros capítulos do livro de Gênesis deveriam ser lidos como uma polêmica que apresenta uma visão diferente sobre Deus.

Gilbert defende a hipótese de que o relato da criação teria sido composto pouco tempo após a saída dos hebreus do Egito. No entanto, não explica o porquê de sua decisão, nem os fatores que o levaram a assumir essa posição, exceto pelo fato de que a hipótese documentária, segundo ele, não tem recebido 
tanta aderência nos últimos anos. Sendo assim, o texto de Gênesis não deveria ser caracterizado como um mito, uma vez que o texto exibe uma sobriedade diferente dos mitos de sua época, a infraestrutura divina mitológica está ausente e o próprio texto cria uma ponte entre os eventos relatados nos primeiros capítulos e as histórias patriarcais encontradas ao longo do livro.

Esse ponto é crucial para o autor, uma vez que sua tese depende da historicidade de Adão e Eva, sua queda, e a corrupção da natureza para o pecado. Ele reconhece que muitos teólogos atualmente evitam discutir os primeiros capítulos de Gênesis em termos literais, mas, conforme advoga, a melhor forma de entender o atual sofrimento da natureza é por meio da cosmovisão estabelecida nos primeiros capítulos de Gênesis.

Ao lidar com questões de origem, Gilbert questiona toda a estrutura científica neodarwiniana. Embora algumas de suas indagações sobre evolução sejam contundentes, muito do que ele questiona faz o leitor se perguntar se Gilbert realmente entende a intrínseca relação entre mutação, seleção natural e tempo profundo proposta por neodarwinistas.

No terceiro capítulo, ele comenta o que significa ser feito à imagem de Deus e sua relação com o governo que o ser humano recebe sobre toda a criação. Conforme fica evidente em sua obra, o livre-arbítrio é um componente essencial da natureza humana. A liberdade de escolha, destaca o autor, não deve ser vista apenas em referência ás decisões e os sentimentos relativos a Deus, mas para com toda a criação. Para que o ser humano possa cuidar e amar a criação, à semelhança de Deus, ele deve ser um agente livre que possa escolher amar genuinamente.

Gilbert defende que o casal foi criado em um estado de neutralidade moral, e para que a criação do ser humano pudesse ser completa, era fundamental que Adão e Eva experimentassem a tentação de comer do fruto. Somente então sua condição de agentes livres estaria completa. Sua proposta, entretanto, faz o leitor se perguntar se realmente houve uma "queda", uma vez que sua condição moral no momento da criação era neutra. Decorrente disso, somos também levados a questionar toda sua defesa da narrativa da queda. Para que seu argumento fosse lógico, Gilbert precisaria primeiro estabelecer uma plataforma moral da qual o ser humano poderia então deixar de existir.

Esse tipo de incoerência interna pode ser encontrado em diversos momentos de sua obra. É comum encontrar Gilbert defendendo ou definindo conceitos sem oferecer evidência ou argumentos a favor, como é o caso de sua afirmação de que Satanás é um ser real.

Embora o livro se apresente como uma obra de rigor acadêmico, ele deixa a desejar em muitos aspectos. Nas notas de rodapé, é comum o autor citar 
ideias ou obras sem especificar a fonte com a página. Quando cita autores clássicos, como Agostinho ou Irineu, não cita fontes primárias, mas sempre recorre a fontes secundárias. Embora se proponha a discutir diversos assuntos relativos ao mal, o autor deixa de se aprofundar em muitos deles.

Um ponto positivo do pensamento de Gilbert é sua disposição em incluir o acaso na teologia que estabelece. Diferente de muitos teólogos e pregadores contemporâneos que recorrem ao determinismo divino ilustrado pelo ditado popular "no governo de Deus não há coincidências, somente providência", Gilbert reconhece que existem momentos que o acaso parece ter a última palavra, embora acabe não fundamentando teologicamente essa possibilidade.

Um aspecto que precisa ser melhorado na argumentação de Pierre é sua tendência exagerada ao antropocentrismo. Diante de todo o avanço astronômico e científico, já é hora de teólogos perceberem que o ser humano é apenas mais um componente do vasto universo criado por Deus. Um pequeno exemplo dessa tendência ubíqua é quando Gilbert procura exaltar o ser humano e destacar sua diferença para com o reino animal, alegando que o "fôlego de vida" é uma característica única do ser humano, quando em outros textos bíblicos claramente mencionam que animais também têm folego de vida (p. 164). O problema do mal e da morte não é uma questão que atinge apenas a espécie humana, mas tem causado sofrimento para toda a criação. Esse aspecto é quase que totalmente ignorado pela obra de Gilbert.

Em resumo, God Never Meant for Us to Die, defende que o plano original de Deus era que a criação gozasse de vida, prosperidade de bem-estar eternos. O motivo pela atual condição da natureza se encontra no pecado e na queda de Adão e Eva. Mesmo assim, o autor falha em explicar qual a relação da desobediência de Adão e Eva para com nosso sofrimento. Embora admita que existe o link, Gilbert não consegue explicar o porquê. Considerando que existem pecados piores mencionados na Bíblia (os de Davi, por exemplo), porque o de Adão e Eva teve consequências tão catastróficas? Essas são algumas das perguntas que deveriam inspirar um aprofundamento do pensamento cristão sobre o problema do mal.

\section{Glauber Souza Araújo}

Doutorando em Teologia Sistemática pela Universidad Adventista del Plata

Libertador San Martín - Argentina

E-mail: glauberaraujo@yahoo.com 